\title{
ANALISIS KONTRIBUSI PENDAPATAN USAHATANI CENGKEH TERHADAP PENDAPATAN RUMAH TANGGA TANI DI DESA DUNGINGIS KECAMATAN DAKO PEMEAN KABUPATEN TOLITOLI (STUDI KASUS PADA KELOMPOK TANI MEKAR 2)
}

\author{
CONTRIBUTION ANALYSIS OF CLOVE FARMING INCOME \\ FOR WARD HOUSEHOLD INCOME IN DUNGINGIS VILLAGE \\ DISTRICT DAKO PEMEAN TOLITOLI DISTRICT \\ (CASE STUDY IN MEKAR 2 TANIGROUP)
}

\author{
Nurmala $^{1}$, Nasrullah ${ }^{1}$, Moh. Asse ${ }^{1}$ \\ ${ }^{1}$ Program Studi Agribisnis, Sekolah Tinggi Ilmu Pertanian Mujahidin Tolitoli \\ Jl. Dr. Samratulangi No. 51 Tuweley Tolitoli Sulawesi Tengah
}

\begin{abstract}
ABSTRAK
Penelitian ini bertujuan untuk mengetahui besarnya pendapatan rumah tangga tani pada usahatani cengkeh dan kontribusi usahatani cengkeh terhadap total pendapatan rumah tangga tani pada Kelompok Tani Mekar 2 di Desa Dungingis Kecamatan Dako Pemean Kabupaten Tolitoli. Penelitian ini dilaksanakan dari bulan Juli sampai September 2018. Metode penelitian yang digunakan yaitu metode sensus dengan sampel sebanyak 20 responden. Hasil dari penelitian ini menunjukkan pendapatan usahatani cengkeh merupakan sumber pendapatan yang berkontribusi paling besar dari semua sumber pendapatan keluarga petani yaitu sebesar Rp.579.277.557,- per tahun atau 56,44\%.
\end{abstract}

Kata kunci: usahatani cengkeh, pendapatan dan kontribusi.

\begin{abstract}
This study aims to determine the amount of farm household income in clove farming and the contribution of clove farming to total farm household income in Mekar 2 Farmer Group in Dungingis Village, Dako Pemean Subdistrict, Tolitoli Regency. This research was conducted from July to September 2018. The research method used was the census method with a sample of 20 respondents. The results of this study indicate that clove farming income is the source of income that contributes the most from all sources of income of farm families, amounting to Rp.579,277,557 per year or $56.44 \%$.
\end{abstract}

Keywords: clove farming, revenue and contribution.

\section{Pendahuluan}

Tanaman cengkeh (Syzigium aromaticum) dikenal sebagai tanaman rempah yang digunakan sebagai obat tradisional. Cengkeh termasuk salah satu penghasil minyak atsiri yang biasa digunakan sebagai bahan baku industri farmasi maupun industri makanan, sedangkan penggunaan yang terbanyak sebagai bahan baku rokok khas Indonesia. Usaha cengkeh merupakan bisnis yang sangat menguntungkan karena mempunyai peluang pasar yang sangat luas. Kesempatan untuk ekspor ke luar negeri masih terbuka lebar sehingga dapat menjadi peluang

\footnotetext{
${ }^{*)}$ Penulis Korespondensi.

E-mail: nurmala880224@yahoo.co.id

Telp: 082348149688
}

untuk menambah devisa.

Cengkeh memegang peranan penting dalam pembangunan perkebunan khususnya pembangunan nasional pada umumnya karena kontribusinya yang nyata dalam penyediaan kebutuhan bahan baku terutama bagi industri rokok kretek, peningkatan pendapatan petani, peningkatan devisa negara, penyediaan kesempatan kerja ditingkat on farm, industri farmasi dan perdagangan serta sektor informal (Nurdjannah, 2007).

Usaha budidaya tanaman cengkeh mayoritas dikelola oleh perkebunan rakyat. Data pada tahun 2016 menunjukkan bahwa dari total areal cengkeh 542.281 ha, seluas 533.120 ha (98\%) dikelola oleh perkebunan rakyat. Sisanya seluas 2.365 ha (1\%) dikelola oleh perkebunan 
besar negara dan 6.796 ha $(1 \%)$ dikelola oleh perkebunan swasta. Produksi cengkeh tahun 2016 sebesar 139.522 ton yang terdiri dari 137.587 ton $(99 \%)$ perkebunan rakyat dan sisanya 415 ton $(0 \%)$ dari perkebunan besar negara dan 1.510 ton $(1 \%)$ dari perkebunan swasta (Direktorat Jendral Perkebunan, 2016).

Sulawesi Tengah memiliki potensi yang sangat sesuai untuk tanaman cengkeh sehingga wilayah ini menjadi salah satu penghasil cengkeh di Indonesia Timur setelah Maluku dan Sulawesi Utara. Produksi cengkeh di Sulawesi Tengah mengalami fluktuasi tiap tahunnya. Tahun 2012 sampai 2014 terjadi peningkatan yang disebabkan oleh iklim yang normal (bulan basah dan bulan kering seimbang), pada tahun 2015 produksi menurun dari 16.444 ton dengan luas lahan 56.554 ha menjadi 14.691 dengan luas lahan 56.554 ha, penurunan produksi cengkeh tersebut diperkirakan terjadi karena beberapa hal diantaranya musim kemarau yang relatif panjang pada tahun 2015. Peningkatan produksi cengkeh kembali terjadi pada tahun 2016 yakni dari 14.691 ton menjadi 17.171 ton dengan luas lahan 68.162 ha, peningkatan produksi tersebut terjadi karena pada tahun 2016 merupakan panen raya (Badan Pusat Statistik Sulawesi Tengah, 2017).

Salah satu kabupaten sentra penghasil cengkeh di Sulawesi Tengah adalah Kabupaten Tolitoli. Tanaman cengkeh di Kabupaten Tolitoli di usahakan secara besar-besaran oleh petani. Sejak harga cengkeh membaik kembali di pasaran, maka dalam kurun waktu beberapa tahun terakhir, produksi cengkeh juga mengalami kenaikan yang cukup berarti. Selain itu, dengan adanya kebijakan pemerintah untuk menghapuskan organisasi BPPC (Badan Penyangga dan Pengelolaan Cengkeh), maka pada tahun 1999 produksi cengkeh kembali membaik. Produksi cengkeh pada tahun 2016 mencapai $10.276,28$ ton, sementara itu luas areal tanaman cengkeh mencapai 37.720 ha yang terdiri dari yang menghasilkan sebanyak 29.619 ha, yang sudah tua 4.152 ha dan yang tanaman muda sebesar 3.949 ha. Salah satu penghasil cengkeh di Kabupaten Tolitoli adalah Kecamatan Dako Pemean yang memiliki jumlah produksi cengkeh sebesar 515 ton, produktivitas diatas rata-rata produksi kecamatan yaitu sebesar 0,41 ton/ha dengan luas lahan 1.264 ha (BPS Kabupaten Tolitoli, 2017).

Kelompok tani dibentuk sesuai kebutuhan dari masyarakat yang memiliki tujuan yang sama dan ingin bekerja sama satu dengan yang lain (Harijati, 2007). Kelompok tani biasanya ditemukan dipedesaan, sebagian besar memiliki mata pencaharian dibidang pertanian atau sebagai petani. Terdapat 3 kelompok tani tanaman cengkeh yang terbentuk di Desa Dungingis Kecamatan Dako Pemean Kabupaten Tolitoli yaitu kelompok tani Mega Jaya, Angin Mamiri dan Mekar 2. Diantara 3 kelompok tani tersebut kelompok tani Mekar 2 merupakan kelompok tani yang anggotanya masih aktif sampai saat ini.

\section{Metode Penelitian}

Jenis penelitian yang dilakukan adalah penelitian deskriptif kuantitatif. Pemilihan lokasi penelitian dilakukan secara sengaja (Purposive). Penelitian ini dilakukan pada kelompok tani Mekar 2 di Desa Dungingis Kecamatan Dako Pemean Kabupaten Tolitoli dengan pertimbangan bahwa kelompok tani Mekar 2 merupakan kelompok tani yang anggotanya masih aktif sampai saat ini. Penelitian dilaksanakan pada bulan juli sampai dengan bulan September 2018. Jumlah populasi yang diambil sebanyak 20 orang petani cengkeh. Teknik pengambilan sampel adalah metode sensus, sehingga jumlah sampel dalam penelitian ini sebanyak 20 orang petani. Jenis dan sumber data yaitu data primer dan data sekunder sedangkan teknik pengumpulan data dengan menggunakan cara obervasi, studi kepustakaan, wawancara dan questioner.

Metode analisis data yang digunakan adalah :

\section{Analisis Pendapatan}

Laba atau pendapatan bersih adalah selisih antara total penerimaan dengan total biaya dalam satu kali proses produksi. Rumus yang digunakan adalah sebagai berikut (Kartosapoetra, 1998) :

$$
\pi=T R-T C
$$

Dimana :

$\pi=$ Pendapatan

$\mathrm{TR}=$ Total Revenue atau total penerimaan

$\mathrm{TC}=$ Total Cost atau total biaya

2. Analisis Pendapatan Rumah Tangga Tani

Pendapatan rumah tangga tani menurut Patty

(2010) dapat ditentukan dengan menggunakan rumus :

$$
\text { Prt }=\text { Put }+ \text { Plut }
$$

Dimana :

$$
\begin{aligned}
& \text { Prt }=\text { Pendapatan rumah tangga tani } \\
& \text { Put }=\text { Pendapatan usahatani } \\
& \text { Plut }=\text { Pendapatan luar usahatani }
\end{aligned}
$$

3. Kontribusi Pendapatan Rumah Tangga Tani 
Analisis kontribusi dilakukan dengan membandingkan persentase pendapatan usahatani cengkeh terhadap total pendapatan rumah tangga petani cengkeh, dengan menggunakan rumus (Suharyanto $d k k, 2004$ )

$$
\mathrm{Kp}=\frac{\sum_{n=1}^{n} P c}{\sum_{n=1}^{n} P r t} \times 100 \%
$$

Dimana :

$\mathrm{Kp}=$ Kontribusi pendapatan cengkeh $(\mathrm{Rp})$

$\mathrm{Pc}=$ Pendapatan cengkeh tunai $(\mathrm{Rp})$

Prt $=$ Total pendapatan rumah tangga tani $(\mathrm{Rp})$

$\mathrm{n} \quad=$ Jumlah sampel observasi

Selanjutnya untuk menentukan besarnya kontribusi pendapatan dari pengolahan cengkeh terhadap total pendapatan rumah tangga petani cengkeh dapat digunakan kriteria yang dikemukakan oleh Widodo (2001) dalam Patty (2010) adalah sebagai berikut :

1. Jika kontribsi pendapatan cengkeh $<25 \%$ pendapatan rumah tangga petani, maka dikategorikan sangat rendah.

2. Jika kontribsi pendapatan cengkeh $25 \%$ 49\% pendapatan rumah tangga petani, maka dikategorikan rendah.

3. Jika kontribsi pendapatan cengkeh 50\% $75 \%$ pendapatan rumah tangga petani, maka dikategorikan tinggi.

4. Jika kontribsi pendapatan cengkeh $>75 \%$ pendapatan rumah tangga petani, maka dikategorikan sangat tinggi.

\section{Hasil dan Pembahasan}

Desa Dungingis adalah salah satu desa dari empat desa yang berada di wilayah Kecamatan Dako Pemean dengan luas wilayah kurang lebih 5.200 ha. Data demografis Desa Dungingis pada tahun 2017 memiliki jumlah penduduk sebesar 2.464 jiwa dengan kepadatan penduduk 47,38 jiwa/km. Kelompok umur terbanyak di Desa Dungingis tergolong pada usia 15 - 64 tahun yaitu sebanyak 1.383 jiwa, hal ini menunjukan bahwa penduduk di Desa Dungingis sebagian besar masih tergolong usia produktif untuk bekerja sehingga masih memungkinkan untuk meningkatkan roduktivitas usahatani yang sedang dilakukan. Tingkat pendidikan penduduk di daerah Desa Dungingis masih tergolong rendah, sehingga sangat mempengaruhi pengetahuan dan pola piker masyarakat, oleh karena itu penduduk di daerah tersebut perlu menambah wawasan pengetahuan dan wawasan melalui pendidikan non formal.

\section{Luas Lahan}

Lahan pertanian merupakan bagian terpenting bagi kehidupan manusia, sebab sebagai penopang kehidupan manusia baik output yang dihasilkan maupun keberadaan sebagai penyeimbang alam (Maryoni, 2016). Lahan merupakan faktor produksi yang penting bagi seorang petani, kerena luas lahan usahatani menentukan pendapatan dan kesejahteraan taraf hidup petani. Semakin luas lahan garapan, maka semakin besar peluang petani dalam mengelola usahataninya. Salah satu pendekatan untuk meningkatkan kesejahteraan petani sehingga keluar dari perangkap kemiskinan adalah peningkatan akses penguasaan lahan oleh petani. Luas lahan usahatani cengkeh pada Kelompok Tani Mekar 2 di Desa Dungingis Kecamatan Galang Kabupaten Tolitoli dapat dilihat pada Tabel 1.

Tabel 1. Luas Lahan Petani Responden pada Kelompok Tani Mekar 2 Desa Dungingis Kecamatan Dako Pemean Kabupaten Tolitoli Tahun 2017.

\begin{tabular}{ccrr}
\hline No. & $\begin{array}{c}\text { Luas Lahan } \\
\text { (ha) }\end{array}$ & $\begin{array}{c}\text { Jumlah } \\
\text { (orang) }\end{array}$ & $\begin{array}{r}\text { Persentase } \\
(\%)\end{array}$ \\
\hline 1 & $0,40-0,59$ & 11 & 55 \\
2 & $0,60-0,79$ & 5 & 25 \\
3 & $>0,80$ & 4 & 20 \\
\hline & Jumlah & 20 & 100 \\
\hline
\end{tabular}

Sumber : Kelompok Tani Mekar 2 Tahun 2017

\section{Produksi Usahatani Cengkeh}

Salah satu tujuan usahatani adalah dicapainya produksi dan pendapatan yang tinggi. Produksi merupakan hasil yang diperoleh petani pada saat panen dengan proses produksi yang menggunakan sumber daya sehingga dapat menghasilkan sesuatu berupa barang, jasa ataupun keduanya. Tingginya produksi usahatani cengkeh diikuti oleh semakin besarnya pendapatan yang diperoleh akan lebih merangsang petani dalam meningkatkan produksinya. Hasil penelitian menunjukkan bahwa produksi petani responden secara keseluruhan untuk usahatani cengkeh pada Kelompok Tani Mekar 2 Desa Dungingis Kecamatan Dako Pemean Kabupaten Tolitoli per periode produksi untuk 12,50 ha sebesar 10.200 $\mathrm{Kg}$ dengan rata-rata sebesar $816 \mathrm{~kg} / \mathrm{ha}$ dari luas lahan rata-rata 0,63 ha (Lampiran 2). Produksi cengkeh pada Kelompok Tani Mekar 2 Desa Dungingis Kecamatan Dako Pemean Kabupaten Tolitoli tergolong tinggi. Hal ini didasarkan pada penelitian Situmeang (2008) yang 
mengungkapkan produktivitas tanaman cengkeh di Indonesia umumnya masih rendah, yaitu berkisar antara $125-250 \mathrm{~kg} / \mathrm{ha}$, sedangkan potensinya dapat mencapai $500-800 \mathrm{~kg} / \mathrm{ha}$.

\section{Biaya Produksi Usahatani Cengkeh}

Biaya produksi adalah semua biaya yang di keluarkan petani dalam suatu proses produksi selama setahun. Biaya produksi cengkeh terdiri dari biaya tetap dan biaya variabel.

1. Biaya Tetap

Biaya tetap adalah biaya yang tidak tergantung dari besar kecilnya volume produksi. Atau biaya tetap adalah biaya yang besar kecilnya tidak dipengaruhi oleh volume produksi dan terus dikeluarkan oleh petani (Yasa dan Hadayani, 2017). Penelitian ini menunjukkan bahwa biaya tetap terdiri dari pajak lahan dan biaya penyusutan. Biaya pajak yang diteliti bervariasi tergantung dari besarnya luasan lahan dan jauh dekatnya lahan terhadap pemukiman penduduk, dimana semakin dekat pemukiman maka biaya pajak lahan semakin besar dan demikian sebaliknya. Jumlah biaya pajak lahan yang dikeluarkan petani responden pada usahatani cengkeh per periode (1 tahun) adalah sebesar Rp.927.526,untuk luas lahan 12,50 ha dengan biaya pajak rata-rata per tahun Rp.74.202,- per ha. Biaya penyusutan diperoleh berbagai macam alat yaitu parang, hand sprayer, linggis, tali, tangga, kemasan, cangkul. Jumlah biaya penyusutan alat yang dikeluarkan oleh petani responden pada usahatani cengkeh per periode (1Tahun) adalah sebesar Rp.35.867.667,- untuk luas lahan sebesar 12,50 ha atau dengan rata-rata penyusutan alat adalah Rp.2.869.413,-- per ha dapat dilihat pada Tabel 2.

Tabel 2. Jumlah Biaya Tetap Usahatani Cengkeh pada Kelompok Tani Mekar 2 Desa Dungingis Kecamatan Dako Pemean Kabupaten Tolitoli Tahun 2017

\begin{tabular}{cccc}
\hline No. & Jenis Biaya & $\begin{array}{c}\text { Jumlah Biaya } \\
(\mathrm{Rp})\end{array}$ & $\begin{array}{c}\text { Biaya/ ha } \\
(\mathrm{Rp})\end{array}$ \\
\hline 1 & Pajak & 927.526 & 74.202 \\
2 & Penyusutan & 35.867 .667 & 2.869 .413 \\
& Alat & & \\
\hline & Jumlah & 36.795 .193 & 2.943 .615 \\
\hline
\end{tabular}

Sumber : Data primer Setelah Diolah tahun 2017

\section{Biaya Variabel}

Biaya variabel adalah biaya yang langsung dipengaruhi oleh besarnya penggunaan pupuk, pestisida, dan tenaga kerja. Biaya variabel juga langsung mempengaruhi besarnya output suatu usaha. jumlah biaya variabel yang dikeluarkan oleh petani responden pada usahatani cengkeh per periode produksi (1 tahun) adalah sebesar Rp 366.021 .250 ,- untuk luas lahan 12,50 ha atau rata-rata Rp 29.281.700,- per ha. Jumlah biaya penggunaan pupuk yang dikeluarkan petani responden pada usahatani cengkeh ialah sebesar Rp 30.800.000,- untuk luas lahan 12,50 ha dengan rata-rata $\mathrm{Rp} 2.464 .000$,- per ha dan untuk jumlah biaya penggunaan pestisida sebesar $\mathrm{Rp}$ 13.290.000,- dengan rata-rata $\mathrm{Rp} 11.063 .200$,per ha, sedangkan untuk jumlah biaya penggunaan tenaga kerja ialah sebesar $\mathrm{Rp}$ 25.754.500,- per ha. Biaya variabel yang digunakan petani cengkeh pada Kelompok Tani Mekar 2 Desa Dungingis Kecamatan Dako Pemean Kabupaten Tolitoli berdasarkan jenisnya. Tabel 3. Jumlah Biaya Variabel Usahatani Cengkeh pada Kelompok Tani Mekar 2 Desa Dungingis Kecamatan Dako Pemean Kabupaten Tolitoli Tahun 2017

\begin{tabular}{cccc}
\hline No Jenis Biayc & $\begin{array}{c}\text { Jumlah Biaya } \\
(\mathrm{Rp})\end{array}$ & $\begin{array}{c}\text { Biaya/ ha } \\
(\mathrm{Rp})\end{array}$ \\
\hline 1 & Pupuk & 30.800 .000 & 2.464 .000 \\
2 & Pestisida & 13.290 .000 & 1.063 .200 \\
3 & Tenaga & 321.931 .250 & 25.754 .500 \\
& Kerja & & \\
\hline & Jumlah & 366.021 .250 & 29.281 .700
\end{tabular}

Sumber: Data primer Setelah Diolah tahun 2017

\section{Penerimaan Usahatani Cengkeh}

Penerimaan dalam suatu usahatani merupakan hasil kali antara produksi fisik dengan harga jual. Penerimaan usahatani petani responden pada usahatani cengkeh per periode produksi (1 tahun) adalah untuk hasil produksi sebesar $10.200 \mathrm{~kg}$ atau senilai Rp.951.500.000,untuk luas lahan sebesar 12,50 ha atau hasil produksi rata-rata $816 \mathrm{~kg} / \mathrm{ha}$ atau senilai Rp.76.120.000,- per ha. Penerimaan yang diperoleh petani responden pada usahatani cengkeh Kelompok Tani Mekar 2 Desa Dungingis Kecamatan Dako Pemean Kabupaten Tolitoli sangat tergantung pada harga cengkeh di tingkat pengumpul. Harga pembelian cengkeh kering sangat fluktuatif, terkadang penjualan setiap musim panen harga cengkeh kering selalu anjlok sehingga penerimaan yang diperoleh petani tidak sesuai dengan yang diharapkan oleh petani. Selain penerimaan dari cengkeh kering, petani responden pada usahatani cengkeh Kelompok Tani Mekar 2 juga memiliki penerimaan lain yang bersumber dari tangkai dengan jumlah penerimaan sebesar Rp.30.594.000,- atau dengan rata-rata Rp.1.529.700,-. Total penerimaan yang di peroleh oleh petani responden pada Kelompok Tani Mekar 2 adalah sebesar Rp.982.094.000,per tahun dengan rata-rata Rp.78.567.520,- per tahun. 


\section{Pendapatan Usahatani Cengkeh}

Pendapatan usahatani

merupakan besaran pendapatan petanikeh, kegiatan usahatani cengkeh Pendapatan usahatani merupakan selisih antara total penerimaan dan total biaya produksi (Rp/tahun). Jumlah pendapatan usahatani cengkeh pada Kelompok Tani Mekar 2 adalah sebesar Rp.579.277.557,- dengan rata-rata pendapatan adalah sebesar Rp.46.342.205,- per ha.

1. Pendapatan Rumah Tangga Tani yang Bersumber dari Usahatani Lain selain Usahatani Cengkeh

Selain dari usahatani cengkeh, pendapatan rumah tangga petani juga diperoleh dari beberapa sumber usahatani lain. Hasil wawancara dengan petani responden, jumlah pendapatan petani dari sumber lain dapat dilihat pada Tabel 19 yang menunjukan total pendapatan yang diperoleh petani di luar usahatani cengkeh adalah sebesar Rp 308.857.186,- per tahun dengan rata-rata pendapatan petani adalah Rp.17.158.733,- per tahun. Pendapatan rumah tangga tani pada Kelompok Tani Mekar 2 Desa Dungingis Kecamatan Dako Pemean Kabupaten Tolitoli di peroleh dari selisih antara total penerimaan dan total biaya produksi ( $\mathrm{Rp} / \mathrm{tahun}$ ), dimana untuk jumlah penerimaan usahatani padi sawah rumah tangga petani responden per periode (1 Tahun) adalah sebesar Rp.579.200.000,- per tahun dengan rata-rata sebesar Rp.32.177.778,- per tahun, untuk penggunaan biayanya berjumlah Rp.293.909.481,- per tahun atau dengan ratarata Rp.16.328.304,- per tahun, sedangkan untuk jumlah penerimaan usahatani ternak sapi pada rumah tangga petani responden selama 1 tahun adalah sebesar Rp.24.000.000,- per tahun dengan jumlah biaya yang di keluarkan sebesar Rp.433.333,- per tahun. Adapun rata-rata penerimaan dan biaya yang dikeluarkan sama dengan jumlah penerimaan dan jumlah biaya karena hanya terdapat 1 orang yang mengusahakan ternak sapi pada tabel 4 .

Tabel 4. Pendapatan Rumah Tangga Tani Dari Usahatani Lain Pada Kelompok Tani Mekar 2 Desa Dungingis Kecamatan Dako Pemean Kabupaten Tolitoli Selain Usahatani Cengkeh Tahun 2017.

\begin{tabular}{ccr}
\hline No. & Jenis & Pendapatan (Rp) \\
& Usahatani & \\
\hline 1 & Padi Sawah & 285.290 .519 \\
2 & Ternak Sapi & 23.566 .667 \\
\hline & Jumlah & 308.857 .186 \\
\hline
\end{tabular}

Sumber : Data primer Setelah Diolah tahun 2017
2. Pendapatan Rumah Tangga Tani Diluar Kagiatan Usahatani

Selain dari usahatani cengkeh dan usahatani lain, pendapatan rumah tangga petani cengkeh juga berasal dari pendapatan non usahatani atau pendapatan yang diperoleh di luar kegiatan usahatani. Tabel 20 menunjukkan bahwa jumlah pendapatan responden dari jenis pekerjaan selain di bidang pertanian adalah sebesar Rp.138.260.000,- per tahun dengan rata-rata pendapatan responden adalah sebesar Rp.34.565.000,- per tahun. Pedapatan tersebut terdiri dari wiraswasta pabrik padi, wiraswasta bengkel, guru honorer dan KAUR Pembangunan. Pendapatan rumah tangga tani responden di peroleh dari selisih antara total penerimaan dan total biaya produksi (Rp/tahun). Penerimaan dari pekerjaan lain berjumlah Rp.196.600.000,- per tahun atau rata-rata Rp.49.150.000,- per tahun. Penerimaan tersebut berasal dari 4 jenis pekerjaan yakni dari wiraswasta pabrik dengan jumlah Rp.160.000.000,- per tahun, dengan total biaya Rp.56.000.000,- per tahun. Jumlah penerimaan wiraswasta bengkel adalah sebesar Rp.15.600.000,- per tahun dengan jumlah biaya sebesar Rp.2.340.000,- per tahun. Sedangkan untuk pekerjaan guru honorer dan KAUR pembangunan jumlah penerimaannya adalah sebesar Rp.3.000.000,- per tahun dan Rp.18.000.000,- per tahun. Kedua pekerjaan tersebut tidak memiliki biaya yang di keluarkan karena tidak adanya pengeluaran yang berkaitan dengan pekerjaan tersebut dapat dilihat pada tabel 5 .

Tabel 5. Pendapatan Rumah Tangga Tani Berdasarkan Jenis Pekerjaan Selain Dibidang Pertanian Pada Kelompok Tani Mekar 2 Desa Dungingis Kecamatan Dako Pemean Kabupaten Tolitoli Tahun 2017

\begin{tabular}{ccr}
\hline No. & Jenis Pekerjaan & \multicolumn{1}{c}{$\begin{array}{c}\text { Pendapatan } \\
(\mathrm{Rp})\end{array}$} \\
\hline 1 & Wiraswasta pabrik padi & 104.000 .000 \\
2 & Wiraswasta bengkel & 13.260 .000 \\
3 & Guru honorer & 3.000 .000 \\
4 & KAUR pembangunan & 18.000 .0000 \\
\hline & Jumlah & 138.260 .000
\end{tabular}

Sumber : Data primer Setelah Diolah tahun 2017

\section{Total Pendapatan Rumah Tangga Petani}

Pendapatan total rumah tangga petani cengkeh terdiri dari seluruh pendapatan yang diperoleh dari usahatani cengkeh, usahatani lain, dan dari usaha lain. Dari hasil penelitian, seluruh pendapatan petani baik dari pendapatan usahatani dan non usahatani, porsi yang paling tinggi adalah pendapatan usahatani cengkeh. Jumlah 
pendapatan dari usahatani cengkeh adalah Rp.579.277.557,-- per tahun atau rata-rata total pendapatan keluarga petani cengkeh adalah sebesar Rp.28.963.878,- per tahun. Pendapatan kedua tertinggi adalah pendapatan usahatani lain dengan jumlah pendapatan sebesar Rp.308.857.186,- per tahun atau rata-rata total pendapatan adalah sebesar Rp.17.158.733,- per tahun. Sedangkan untuk sumber pendapatan terendah yakni pendapatan yang berasal dari pekerjaan lain dengan jumlah pendapatan Rp.138.260.000,- per tahun atau dengan rata-rata pendapatan sebesar Rp.34.565.000,- per tahun. Sehingga untuk total keseluruhan pendapatan rumah tangga tani pada kelompok tani Mekar 2 Desa Dungingis Kecamatan Dako Pemean Kabupaten Tolitoli adalah sebesar Rp.1.026.394.743,- per tahun atau dengan ratarata pendapatan sebesar Rp.51.319.737,- per tahun.
4. Kontribusi Pendapatan Usahatani Cengkeh Terhadap Total Pendapatan Keluarga Petani

Kontribusi adalah sumbangan atau bagian, kontribusi usahatani cengkeh terhadap pendapatan keluarga petani adalah besarnya sumbangan atau bagian pendapatan dari usahatani cengkeh terhadap keseluruhan pendapatan petani dari usahataninya. Besarnya kontribusi pendapatan usahatani cengkeh dapat dilihat dari Tabel 6. Tabel tersebut menunjukkan bahwa kontribusi pendapatan tertinggi yang berasal dari usahatani cengkeh dibandingkan lainnya.

Tabel 6. Kontribusi Pendapatan Usahatani Cengkeh Tergadap Pendapatan Rumah Tangga Tani Pada Kelompok Tani Mekar 2 Desa Dungingis Kecamatan Dako Pemean Kabupaten Tolitoli Tahun 2017

\begin{tabular}{clcc}
\hline No. & $\begin{array}{c}\text { Sumber } \\
\text { Pendapatan }\end{array}$ & $\begin{array}{c}\text { Pendapatan } \\
(\mathrm{Rp})\end{array}$ & $\begin{array}{c}\text { Kontribusi } \\
(\%)\end{array}$ \\
\hline 1 & Usahatani & 579.277 .557 & 56,55 \\
& cengkeh & 308.857 .186 & 30,09 \\
2 & Usahatani lain & 138.260 .000 & 13,47 \\
3 & Diluar usahatani & & \\
\hline & Jumlah & 1.026 .394 .743 & 100 \\
\hline
\end{tabular}

Sumber: Data primer Setelah Diolah tahun 2017

\section{Daftar Pustaka}

Abas, A., Noer, H. \& If'all (2019). Faktor-Faktor Yang Mempengaruhi Produksi Tanaman Padi Gogo Di Kabupaten Morowali. Jurnal Agrotech, 9(1), 16-25.

Badan Pusat Statistik. 2017. Kabupaten Tolitoli Dalam Angka 2017..

Badan Pusat Statistik. 2017. Provinsi Sulawesi Tengah Dalam Angka 2017.

Direktorat Jendral Perkebunan. 2016. Statistik Perkebunan Indonesia Cengkeh 20152017.

Harijati, 2007. Sumber Daya Manusia dan Kinerja Petani Sebagai Basis Pengembangan Ekonomi Lokal. Studi Kasus Desa Tegallega Kecamatan Warungkondang Kabupaten Cianjur. Jurnal ASAPPK. Vol.12.

Maryoni, S. H. 2016. Pengaruh Luas Lahan Pertanian dan Biaya Pemeliharaan Terhadap Pendapatan Petani (Studi Kasus Desa Kepenuhan Raya). Jurnal Ilmiah Cano Ekonomos. 5(1) : 41 - 48 .

Nurdjannah, N. 2007. Diversifikasi Penggunaan Cengkeh, Bogor : Balai Besar Penelitian dan Pengembangan Pasca Panen Pertanian Indonesian.

Patty. Z. 2010. Kontribusi Komoditi Kopra Terhadap Pendapatan Rumah Tanggan Tani Di Kabupaten Halmahera Utara. Jurnal Agroforestri, 3 (5) : 212 - 220.

Suharyanto, Suprapto dan Rubiyo. 2004. Analisis Pendapatan dan Distribusi Pendapatan Usahatani Tanaman Perkebunan Berbasis Kelapa di Kabupaten Tabanan. Bali. Jurnal Pengkajian dan Pengembangan Teknologi Pertanian, 2(7) : $146-154$.

Yasa, A, N, I dan Hadayani. 2017. Analisis Produksi dan Pendapatan Usahatani Padi Sawah di Desa Bonemarawa Kecamatan Riopakava Kabupaten Donggala. Donggala. e-j. Agrotekbis, 5(1) : 111-11 
e-ISSN : 2621-7236

p-ISSN : 1858-134X 